A Journal of Culture, English Language, Teaching $\&$ Literature

ISSN 1412-3320 (Print), ISSN 2502-4914(Online)

Vol. 16 No. 2; December 2016

Copyright (C) Soegijapranata Catholic University, Indonesia

\title{
RELATIONSHIP BETWEEN GENDER, SUBJECT PREFERENCE AND LEARNING STYLES
}

\section{Suprihadi \& Atik Rokhayani}

English Education Department, Teacher Training and Education Faculty, Muria Kudus University, Kudus, Indonesia

$\mathrm{Ph}:$

$+628562758418$

$+6285640065312$

Received: 04-08-2016

Published: 28-02-2017 


\title{
RELATIONSHIP BETWEEN GENDER, SUBJECT PREFERENCE AND LEARNING STYLES
}

\author{
Suprihadi and Atik Rokhayani
}

suprihadi@umk.ac.id; atik.rokhayani@umk.ac.id

English Education Department, Teacher Training and Education Faculty, Muria Kudus University, Kudus, Indonesia

\begin{abstract}
Understanding the learning styles of the students is very crucial in implementing student-centered learning (SCL). The objectives of this research are to describe: 1) the general learning styles profile of the students of English Education Department, Muria Kudus University; 2) the dependency relationship between learning styles dimensions and gender, and 3) the dependency relationship between subject preference and learning styles dimensions. The participants of this research were 208 students from different semesters as the samples, while the instrument is the Indonesian translation of Solomon-Felder Index of Learning Styles Questionnaire. The result of the analysis reveals that: 1) the general learning style profile of the students is balanced; 2) at $\alpha .05$, there is no significant relationship between the probability of the students of having certain learning styles dimensions and gender; 3 ) at $\alpha .05$, the subject preference of the students who are Sensing-Intuitive and Visual - Verbal depends on their learning style dimensions, while that of those who are Active - Reflective and Sequential - Global does not.
\end{abstract}

Key words: learning styles, gender, subject preference, studentcentered learning (SCL)

Abstrak: Memahami gaya belajar mahasiswa sangat penting dalam pembelajaran berbasis mahasiswa (SCL). Tujuan penelitian ini adalah untuk mendekripsikan: 1) profil umum gaya belajar mahasiswa Program Studi Pendidikan Bahasa Inggris Universitas Muria Kudus; 2) hubungan sebab akibat antara dimensi-dimensi gaya belajar dengan jenis kelamin, dan 3) hubungan sebab akibat antara dimensi-dimensi 
gaya belajar dengan mata kuliah kesukaan. Subjek penelitian ini adalah 208 mahasiswa dari semester yang berbeda sebagai sampel, sementara instrumen yang digunakan adalah terjemahan dalam bahasa Indonesia dari Index of Learning Styles Questionnaire karya Solomon dan Felder. Hasil analisis menunjukkan bahwa: 1) profil gaya belajar mahasiswa PBI UMK) adalah seimbang; 2) pada $\alpha .05$, tidak ada hubungan yang signifikan antara dimensi-dimensi gaya belajar dengan jenis kelamin; 3) pada $\alpha .05$, kesukaan mahasiswa yang Sensing - Intuitive dan Visual Verbal terhadap mata kuliah tertentu tergantung pada dimensi-dimensi gaya belajar mereka, sementara mereka yang Active - Reflective dan Sequential - Global tidak.

Kata kunci: gaya belajar, jenis kelamin, mata kuliah kesukaan, pembelajaran berbasis mahasiswa (SCL)

\section{INTRODUCTION}

Understanding the learning styles of the students is very important when the curriculum implemented is competency-based. This is because in competency-based curriculum learning materials and learning processes are designed and oriented to the achievements of the intended competencies and that on the interest of the students (Departemen Pendidikan Nasional, 2005). By understanding the learning styles of the students, it is hoped that teachers can give the best facilitation and motivation to promote their learning. The information about the learning styles of the students will make it easier for the teacher to guide the students to use the best possible way of learning.

The importance of understanding the learning styles of the students is supported by the facts that 1) there is a relationship between learning styles and sex variable (Reid, 1987, p. 1), and 2) there is a relationship between learning styles and students' learning, such as influencing the ways different students learn grammar (Oxford \& Lee, 2007, p. 124). That is why undertaking a research on the learning styles of the students of English Education Department (EED) in Muria Kudus University (MKU) to describe their general learning styles profile, the dependency relationship between learning styles dimensions and gender, and the dependency relationship between learning styles dimensions and subject preference 
becomes very important so as to support the implementation of competency-based curriculum in EED MKU, in which the learning approach must be student-centered.

\section{LITERATURE REVIEW}

\section{A. Defining Learning Styles}

The term learning styles are defined differently by different writers and scholars, but mostly refer to a signal of individual differences (Abidin, Rezaee, Abdullah, \& Singh, 2011). Felder and Henriques (1995) describe learning styles as the ways in which an individual characteristically acquires, retains, and retrieves information. Meanwhile, Cohen (1998) defines learning styles simply as general approaches to learning. The Summer Institute of Linguistics International (SIL International) (1999) proposes a more detailed definition of learning styles as the unique collection of individual skills and preferences that affect how a person perceives, gathers, and processes information. Learning styles affect how a person acts in a group, learns, participates in activities, relates to others, solves problems, teaches, and works (SIL International, 1999).

\section{B. Learning Styles Classification}

Different classifications of learning styles exist in literature, each of which is with its theoretical bases and are rooted to different disciplines. Montemayor, Apiaten, Mendoza, \& Perey (2009) notice that experts classify learning styles as visual learners, auditory learners, kinesthetic learners, and tactile learners. Meanwhile, Reid (1987) classifies learning style preferences into six elements, i.e. visual, auditory, kinesthetic, tactile, group learning, and individual learning.

Felder and Silverman (1988) proposed a learning-style model, consisting of 4 dimensions: 1 ) sensory - intuitive; 2) visual - auditory; 3 ) inductive - deductive; and 4) sequential - global. In 1991, Solomon and Felder of North Carolina University created the initial version, called Index of Learning Style (ILS), based on Felder and Silverman's model of dimensions of learning and teaching styles (Felder\& Spurlin, 2005). They made two significant changes in the model: dropping the inductive/deductive dimensions and changing the visual/auditory category to visual/ verbal. This change was then reinforced by Felder himself in June 2002 with his preface attached to the original article 
(2002). Hence, the model which is currently available and known as Index of Learning Style (ILS) and is used as the instrument of this research assesses preferences on four dimensions of learning styles: 1) sensing-intuitive; 2) visual-verbal; 3) active-reflective, and 4) sequential-global.

The characteristics of learners within each dimension of the learning styles model proposed by Felder \&Solomon (2012) can be described as follows:

1. Active and reflective learners

active learners

a. tend to retain and understand information best by doing something active with it-discussing or applying it or explaining it to others

b. respond to a problem: "Let's try it out'.

c. Prefer doing group work

d. very hard not to do anything physical while having lectures other than taking notes

reflective learners

a. prefer to think about it quietly first

b. respond to A problem by saying: "Let's think it through first"

c. prefer working alone

d. hard not to do anything physical while having lectures other than taking notes

2. Sensing and intuitive learners sensing learners

a. tend to like learning facts 
b. like solving problems by well-established methods and dislike complications and surprises

c. tend to be patient with details and good at memorizing facts and doing hands-on (laboratory) work

d. tend to be more practical and careful than intuitors

e. don't like courses that have no apparent connection to the real world

\section{intuitive learners}

a. don't like courses that have no apparent connection to the real world

b. often prefer discovering possibilities and relationships

c. like innovation and dislike repetition

d. may be better at grasping new concepts and are often more comfortable than sensors with abstractions and mathematical formulations.

e. tend to work faster and to be more innovative than sensors

f. don't like "plug-and-chug" courses that involve a lot of memorization and routine calculations

\section{Visual and verbal learners}

\section{visual learners}

a. remember best what they see--pictures, diagrams, flow charts, time lines, films, and demonstrations

b. learns more when information is presented both visually and verbally

\section{verbal learners}

a. get more out of words-written and spoken explanations

b. learns more when information is presented both visually and verbally 


\section{Sequential and global learners}

\section{sequential learners}
a. tend to gain understanding in linear steps, with each step following logically from the previous one
b. tend to follow logical stepwise paths in finding solutions

\section{global learners}
a. tend to learn in large jumps, absorbing material almost randomly without seeing connections, and then suddenly "getting it"
b. may be able to solve complex problems quickly or put things together in novel ways once they have grasped the big picture, but they may have difficulty explaining how they did it

\section{The Role of Learning Styles in Learning Process and Performance}

Learning styles is one of the variables that influence how students learn (Reid, 1987; Benson, 2001). In a study which examined the different learning strategies by college students in a hypermedia assisted language learning setting for whom English was a second language, Liu \& Reed (1994) concluded that different learning style groups employed different learning strategies in accomplishing the same task. Meanwhile, Sriachanyachon (2012) revealed two important findings related with learning style: 1) there were positive relationships among students' English background knowledge, learning styles, and motivation at 0.05; and 2) a greater variety of learning styles and more motivation to learn English were found with students with higher English background knowledge.

Investigating the effects of cognitive learning style on first-year academic performance in 19 university courses using a sample of 4,546 students over a 4-year period from 1993 to 1997, Drysdale, Ross \& Schulz (2001) revealed that academic performance based on learning style was 
found to be significant $(\mathrm{p}<0.05)$ in 11 of the 19 courses. Two important results of the research on perceptual learning styles by using The Learning Styles Survey (LSS) conducted by Abidin, et al. (2011) are: 1) there is a significant relationship between overall academic achievement and learning styles, 2) the high moderate and low achievers have a similar preference pattern of learning in all learning styles.

\section{Learning Styles, Gender, and Subject Preference}

It is undeniable that men and women are basically different in many aspects, both physically and mentally. Gender is also a variable which is believed to have a relationship with learning style preferences (Reid, 1987) and one that affects learning process as well as learning performance. Wardhaugh (1992) also states that women and men may have different paralinguistic systems and move and gesture differently. Furthermore, Trudgill (1985) says that males' and females' speeches are not only different; and females' are also better than males'. Vasyura (2008) points out that male are more confident in communicative activity. In addition, O'Brien (1991) revealed distinctive differences in cognitive styles between males and females as well as systematic differences associated with major area of study, level of academic achievement, and educational level. If sex variable has a relationship with learning process and learning outcome, it is very possible that it also has a relationship with learning styles.

Another issue, which is also interesting, is the relationship between learning style preferences and the subjects, the students are mostly like this because the characteristics of learners within each learning style are different (Felder \& Solomon). When learning activities match our learning style preferences, we will find them satisfying and motivational, but if they do not, we are less likely to persevere (SIL International, 1999). Hence, it is very logical to think that an individual with certain learning styles will naturally tend to prefer certain subjects. A student with very strong verbal learning style, for instance, is assumed to prefer speaking more than writing. This is supported by the fact that learning styles influence the ways different students learn grammar (Oxford and Lee, 2007) and the students' listening behaviour (Macaro, et.al., 2007). The information about the learning styles of the students will make it easier for the teacher to facilitate the students in the learning process.

\section{METHODS}




\section{A. Research Design}

This research uses mixed-method, because it mixes or combines qualitative and quantitative research methods (Johnson \& Onwuegbuzie, 2004). The method is used to identify and describe the learning styles of the students of EED MKU. The variables of this research are learning styles dimensions, gender, and subject preference. The learning styles dimensions of the students refer to Solomon-FelderLearning Style Model. The gender and the subject preference of the students are identified from the answer sheets (see Appendix).

\section{B. Data Collection}

The subjects of this research are the students of EED MKU. The number of the respondents is 208, comprising students of different semesters. The respondents were randomly selected from each semester by using simple random sampling techniques. To identify the learning styles of the students, we use a self-scoring web-based instrument called SolomonFelder Index of Learning Styles Questionnaire, which has been translated into Indonesian under the permission of Richard M. Felder (2013). This learning style inventory is a 44-question instrument to assess preferences on the four dimensions of the Solomon-Felder model, i.e. sensingintuitive, visual-verbal, active-reflective, and sequential-global.

To ease the process of identification and due to the limitation of the computer and the internet access, we gave the students the Indonesian written version of the questionnaire first. The students had to answer the 44 questions in a separate answer sheet, in which they also had to give the data about their gender and subject preference. After that, we entered the students' answers into the questionnaires on the site which provides the questionnaire and immediately got the results (see Appendix).

\section{Data Analysis and Interpretation}

Analysis of the responses of the students to the questionnaire was done as follows. First, the responses were automatically analyzed by the program of the site as soon as the responses from the respondents were submitted online. The submission was done by the researchers. 
The results of the first step were scores of each respondent for each learning styles dimensions, which were put in scales. Score $1-3$ on the scale indicates that the individual is well balanced on the two dimensions of that scale, score $5-7$ indicates a moderate preference for one dimension of the scale, and score 9 - 11 indicates a very strong preference for one dimension of the scale (see Appendix).

The next step in the data analysis was sorting the learning styles (dimension and category) based on gender and subject preference variables. Afterwards, the researchers conducted a Chi-square test of independence to test the dependency relationship between learning styles dimensions and gender and subject preference variables at $\alpha .05$ in the proper degree of freedom $(d f)$.

\section{FINDINGS AND DISCUSSION}

From the Index of Learning Styles Questionnaire that has been distributed to the respondents, the result is described as follows.

\section{A. General Learning Styles Profile}

The general learning styles profile of the students of EED MKU is illustrated in Table 1. Comparing balanced, moderate, and very strong categories, we can see from Table 1 that the most dominant learning style of the students of EED UMK in the four dimensions is balanced. The average for this category is $\left(\frac{62.50+57.21+49.52+71.15}{4}\right)=60.10 \%$

Knowing the students' learning style will help us plan for learning tasks such as language learning. The importance of students' understanding their own learning styles is supported by Nelson et.al. (1993) who found that students who completed learning style inventories at the beginning of the course achieved better at the end, and those students who were participating in learning style workshops persisted in the universities in larger percentages than those who did not participate in the workshops. Therefore, knowing the fact that balanced is the most dominant category for all learning styles dimensions of the students of EED MKU, it will actually make both the students and the lecturers easier to facilitate the students' learning. This is because balanced category of learning styles is desirable (Felder \& Solomon, 2012). 
Students who are balanced can perceive, organize, process, and understand information in both dimensions of the learning styles more easily than those who are moderate, let alone very strong in one dimension. For example, a balanced verbal - visual student can perceive, organize, process, and understand information transmitted either verbally or visually or both visually and verbally with the same possibility of being successful. In this way the lecturers can choose to deliver the information, i.e. the learning material, either visually or verbally. In other words, devising alternative instructional situations to accommodate the variations in learning styles that may exist in a classroom will be better (Reid, 1987).

\section{Table 1}

General learning styles profile of the students of EED UMK for the four learning styles dimensions

\begin{tabular}{|c|c|c|c|}
\hline Learning Styles & Category & $f$ & $\%$ \\
\hline \multirow{5}{*}{ 1. Active - Reflective } & Balanced & 130 & 62.50 \\
\hline & Moderate Active & 48 & 23.08 \\
\hline & Moderate & 20 & 9.62 \\
\hline & Very Strong & 9 & 4.33 \\
\hline & Very Strong & 1 & 0.48 \\
\hline & Total & 208 & 100 \\
\hline \multirow{6}{*}{ 2. Sensing - Intuitive } & Balanced & 119 & 57.21 \\
\hline & Moderate & 63 & 30.29 \\
\hline & Moderate & 3 & 1.44 \\
\hline & Very Strong & 21 & 10.10 \\
\hline & Very Strong & 2 & 0.96 \\
\hline & Total & 208 & 100 \\
\hline \multirow{6}{*}{ 3. Visual - Verbal } & Balanced & 103 & 49.52 \\
\hline & Moderate Visual & 65 & 31.25 \\
\hline & Moderate Verbal & 1 & 0.48 \\
\hline & Very Strong & 39 & 18.75 \\
\hline & Very Strong & 0 & 0.00 \\
\hline & Total & 208 & 100 \\
\hline \multirow{3}{*}{$\begin{array}{l}\text { 4. Sequential - } \\
\text { Global }\end{array}$} & Balanced & 148 & 71.15 \\
\hline & Moderate & 36 & 17.31 \\
\hline & Moderate Global & 17 & 8.17 \\
\hline
\end{tabular}




\begin{tabular}{rll} 
Very Strong & 7 & 3.37 \\
Very Strong & 0 & 0.00 \\
\hline Total & 208 & 100 \\
\hline
\end{tabular}

In accordance with the implementation of student-centered learning (SCL), understanding the learning styles of the students becomes more crucial. It will make it easier for the teacher to guide the students to use the best possible method of inquiry and discovery. For the students themselves, understanding their own learning styles will make them easier to utilize their preferred learning styles and to take deliberate advantage of those preferences (Reid, 1987).

The fact that the students of EED MKU are not dominated by moderate and very strong categories of learning styles dimensions is also an advantage for EED MKU. With regards to the numbers and percentages, it is found that the department should give more attention to $30.41 \%$ of the students who are moderate and $9.50 \%$ of those who are very strong in one dimension. In addition, between the two categories, students with a very strong preference for one dimension need more attention than the former ones. This is because they may have real difficulty learning in an environment which does not support that preference (Reid, 1987; Felder \&Spurlin, 2005; SIL International, 1999). From Table 1 we can see that $4.33 \%$ of the students are in the very strong active category. If this fact is held as a hypothesis, the teacher should create a learning environment which gives a chance to the students to be active and to work in groups.

The same consideration should also be applied to $10.10 \%$ of the students who are very strong sensing and $18.75 \%$ who are very strong visual. Sensors remember and understand information best if they can see how it connects to the real world, while visual learners remember best what they see such as pictures, diagrams, and films (Felder \& Solomon, 2012; Felder \& Spurlin, 2005).

Language instruction that involves a great deal of repetitive drill and memorization of vocabulary and grammar is good for sensors, while showing photographs, drawings, and sketches to reinforce presentation of vocabulary words is appropriate for visual learners (Felder \& Henriques, 1995).

\section{B. Relationship between learning styles dimensions and gender}


The number of the subjects of this research is 208, comprising of 69 males and 139 females. Table 2 presents the learning styles of the students of EED MKU based on gender variable. Table 2 shows us that for the four dimensions, balanced category for both males and females is the most dominant category.

Comparing between males and females, we can see that the percentage of males who are balanced $(60.51 \%)$ is a little bit higher than that of females (59.89\%). Furthermore, for moderate and very strong categories the percentages are relatively the same for both males and females: $30.43 \%$ and $30.40 \%$ for moderate and $9.06 \%$ and $9.71 \%$ for very strong.

\section{Table 2}

The learning styles profile of the students of EED UMK based on gender variable

\begin{tabular}{|c|c|c|c|c|c|c|c|c|c|c|}
\hline \multirow{3}{*}{$\begin{array}{l}\text { Categ } \\
\text { ory }\end{array}$} & \multicolumn{8}{|c|}{ Learning Styles Dimension } & \multirow{2}{*}{\multicolumn{2}{|c|}{ Total }} \\
\hline & \multicolumn{2}{|c|}{$\begin{array}{c}\text { Active - } \\
\text { Reflective }\end{array}$} & \multicolumn{2}{|c|}{$\begin{array}{c}\text { Sensing - } \\
\text { Intuitive }\end{array}$} & \multicolumn{2}{|c|}{$\begin{array}{l}\text { Visual - } \\
\text { Verbal }\end{array}$} & \multicolumn{2}{|c|}{$\begin{array}{c}\text { Sequential } \\
\text { - Global }\end{array}$} & & \\
\hline & $f$ & $\%$ & $f$ & $\%$ & $f$ & $\%$ & $f$ & $\%$ & $f$ & $\%$ \\
\hline Male & & & & & & & & & & \\
\hline $\begin{array}{l}\text { Balan } \\
\text { ced } \\
\text { Mode } \\
\text { rate } \\
\text { Very }\end{array}$ & $\begin{array}{l}4 \\
4 \\
2 \\
2\end{array}$ & $\begin{array}{c}63 \\
77 \\
31 \\
88\end{array}$ & $\begin{array}{l}4 \\
4 \\
1 \\
8\end{array}$ & $\begin{array}{c}63 . \\
77 \\
26 \\
09\end{array}$ & $\begin{array}{l}3 \\
0 \\
2 \\
4\end{array}$ & $\begin{array}{c}43 . \\
48 \\
34 \\
78\end{array}$ & $\begin{array}{l}4 \\
9 \\
2 \\
0\end{array}$ & $\begin{array}{c}71 . \\
01 \\
28 . \\
99\end{array}$ & $\begin{array}{l}1 \\
6 \\
7 \\
8 \\
4\end{array}$ & $\begin{array}{c}60 . \\
51 \\
30 . \\
43\end{array}$ \\
\hline Stron & & 4.3 & & 10. & 1 & 21. & & 0.0 & 2 & 9.0 \\
\hline g & 3 & 5 & 7 & 14 & 5 & 74 & 0 & 0 & $\begin{array}{l}5 \\
2\end{array}$ & 6 \\
\hline Total & $\begin{array}{l}6 \\
9 \\
\end{array}$ & $\begin{array}{l}100 \\
.00 \\
\end{array}$ & $\begin{array}{l}6 \\
9 \\
\end{array}$ & $\begin{array}{l}100 \\
.00\end{array}$ & $\begin{array}{l}6 \\
9\end{array}$ & $\begin{array}{l}100 \\
.00 \\
\end{array}$ & $\begin{array}{l}6 \\
9 \\
\end{array}$ & $\begin{array}{l}100 \\
.00\end{array}$ & $\begin{array}{l}7 \\
6 \\
\end{array}$ & $\begin{array}{l}100 \\
.00 \\
\end{array}$ \\
\hline $\begin{array}{l}\text { Femal } \\
e\end{array}$ & & & & & & & & & & \\
\hline $\begin{array}{l}\text { Balan } \\
\text { ced }\end{array}$ & $\begin{array}{l}8 \\
6\end{array}$ & $\begin{array}{l}61 . \\
87\end{array}$ & $\begin{array}{l}7 \\
5\end{array}$ & $\begin{array}{l}53 . \\
96\end{array}$ & $\begin{array}{l}7 \\
3\end{array}$ & $\begin{array}{c}52 . \\
52\end{array}$ & $\begin{array}{l}9 \\
9\end{array}$ & $\begin{array}{l}71 . \\
22\end{array}$ & $\begin{array}{l}3 \\
3 \\
3 \\
1\end{array}$ & $\begin{array}{l}59 . \\
89\end{array}$ \\
\hline $\begin{array}{l}\text { Mode } \\
\text { rate }\end{array}$ & $\begin{array}{l}4 \\
6\end{array}$ & $\begin{array}{l}33 . \\
09\end{array}$ & $\begin{array}{l}4 \\
8\end{array}$ & $\begin{array}{l}34 . \\
53\end{array}$ & $\begin{array}{l}4 \\
2\end{array}$ & $\begin{array}{l}30 . \\
22\end{array}$ & $\begin{array}{l}3 \\
3\end{array}$ & $\begin{array}{l}23 \\
74\end{array}$ & $\begin{array}{l}6 \\
9\end{array}$ & $\begin{array}{l}30 . \\
40\end{array}$ \\
\hline
\end{tabular}


254 Celt, Volume 16, Number 2, December 2016, pp. 242-270

\begin{tabular}{lcccccccccc} 
Very & & & & & & & & & \\
Stron & & 5.0 & 1 & 11. & 2 & 17. & & 5 & 9.7 \\
$\mathrm{~g}$ & 7 & 4 & 6 & 51 & 4 & 27 & 7 & 4 & 4 & 1 \\
\hline & 1 & & 1 & & 1 & & 1 & & 5 & \\
& 3 & & 3 & & 3 & & 3 & & 5 & \\
Total & 9 & 100 & 9 & 100 & 9 & 100 & 9 & 100 & 6 & 100 \\
\hline
\end{tabular}

From Table 2 we then analyze the dependency relationship between gender variable and learning styles dimension. More specifically, the analysis is done to answer the question "Is each learning styles dimension affected by gender?" The gender variable consists of 2 categories (Male and Female), while the learning styles dimension consists of 5 categories (Balanced, Moderate for the $1^{\text {st }}$ dimension, Moderate for the $2^{\text {nd }}$ dimension, Very Strong for the $1^{\text {st }}$ dimension, Very Strong for the $2^{\text {nd }}$ dimension). To do this, we did Chi-square test of independence in the level of significance $(\alpha) .05$ and degree of freedom $(d f)(c-1)(r-1)=(2-1)(5-$ $1)=4$. The result of the analysis is summarized in Table 3 .

Table 3 below indicates that at $\alpha=.05$ and $d f=4$, all the $X^{2}$ s do not fall in the critical region, because they are smaller than the $\chi^{2}$ (critical). In other words, we conclude that there is no significant dependency relationship between gender and learning styles dimensions: the probability of the students of having certain learning styles dimension is independent on the gender of the students.

The fact that there is no significant relationship between learning styles and gender is also an advantage for EED MKU, although it is not the same as that of Reid (1987). This will make it easier for both students and lecturers to arrange the learning processes because, in terms of learning styles, they do not have to pay much attention to gender variable.

Table 3

Summary of the result of chi-square test of independence between gender and learning styles dimensions at $X^{2}{ }_{.05} ; d f=4=9.488$

\begin{tabular}{llll}
\hline $\begin{array}{l}\text { Independent } \\
\text { Variable }\end{array}$ & $\begin{array}{l}\text { Dependent } \\
\text { Variable }\end{array}$ & $\begin{array}{l}\boldsymbol{X}^{2} \\
\text { (obtained) }\end{array}$ & Conclusion \\
\hline Gender & $\begin{array}{l}\text { Active }- \\
\text { Reflective }\end{array}$ & 5.579 & not
\end{tabular}




\begin{tabular}{llll}
\hline & dimension & & significant at \\
& & $\alpha .05 ; d f=4$ \\
& & & not \\
Gender & Sensing - & & significant at \\
& Intuitive & 9.148 & $\alpha .05 ; d f=4$ \\
& dimension & & not \\
Gender & Visual - & & significant at \\
& Verbal & 8.432 & $\alpha .05 ; d f=4$ \\
& dimension & & not \\
Gender & Sequential - & & significant at \\
& Global & 8.292 & $\alpha .05 ; d f=4$ \\
\hline
\end{tabular}

C. Relationship between learning styles dimensions and subject preference

The learning style profile of the students of EED UMK based on subject preference is presented in Table 4. The subject preference is categorized into 6: 1) Listening, 2) Speaking, 3) Reading, 4) Writing, 5) None, and 6) Others. As it has been described before, the learning styles are classified into 4-scale dimensions, each of which is classified into 5 categories. From Table 4 we can see that balanced is still the most dominant category for all learning styles dimensions. Among the balanced categories, however, sequential - global dimension is the highest (70.67\%), followed by active - reflective $(62.50 \%)$, sensing - intuitive (57.21\%), and the lowest visual - verbal (49.52\%).

Table 4

The learning styles profile of the students of EED UMK based on subject preference

\begin{tabular}{|c|c|c|c|c|c|c|c|c|c|}
\hline \multirow{3}{*}{$\begin{array}{l}\text { Learning } \\
\text { Styles } \\
\text { Dimensio }\end{array}$} & \multirow{3}{*}{ Category } & \multicolumn{6}{|c|}{ Subject Preference } & \multicolumn{2}{|c|}{ Total } \\
\hline & & 1 & 2 & 3 & 4 & 5 & 6 & & \\
\hline & & $f$ & $f$ & $F$ & $f$ & $f$ & f & $f$ & $\%$ \\
\hline \multirow{5}{*}{$\begin{array}{l}\text { Active - } \\
\text { Reflective }\end{array}$} & Balanced & 1 & 4 & 2 & 1 & 1 & 1 & 1 & 62. \\
\hline & Moderate Active & 8 & 1 & 1 & 8 & 3 & 2 & 4 & 23. \\
\hline & Moderate & 5 & 5 & 4 & 2 & 2 & 4 & 2 & 10. \\
\hline & Very Strong Active & 0 & 4 & 0 & 3 & 0 & 0 & 7 & 3.3 \\
\hline & Very Strong & 0 & 0 & 1 & 0 & 0 & 0 & 1 & 0.4 \\
\hline
\end{tabular}




\begin{tabular}{llllllllll} 
& & 2 & 7 & 4 & 2 & 1 & 2 & 2 & 100 \\
\hline \multirow{3}{*}{ Sensing - } & Balanced & 1 & 4 & 2 & 1 & 9 & 1 & 1 & 57. \\
Intuitive & Moderate Sensing & 1 & 1 & 1 & 1 & 6 & 3 & 6 & 30. \\
& Moderate Intuitive & 0 & 1 & 2 & 0 & 0 & 0 & 3 & 1.4 \\
& Very Strong & 0 & 8 & 5 & 4 & 0 & 2 & 1 & 9.1 \\
& Very Strong & 0 & 0 & 0 & 1 & 2 & 0 & 3 & 1.4 \\
\hline \multirow{3}{*}{ Visual - } & & 2 & 7 & 4 & 2 & 1 & 2 & 2 & 100 \\
Verbal & Balanced & 1 & 3 & 2 & 1 & 6 & 1 & 1 & 49. \\
& Moderate Visual & 9 & 2 & 1 & 8 & 1 & 6 & 6 & 32. \\
& Moderate Verbal & 7 & 1 & 0 & 0 & 0 & 0 & 8 & 3.8 \\
& Very Strong Visual & 0 & 1 & 5 & 6 & 0 & 5 & 3 & 14. \\
& Very Strong Verbal & 0 & 0 & 0 & 0 & 0 & 0 & 0 & 0 \\
\hline \multirow{3}{*}{ Sequentia } & 2 & 7 & 4 & 2 & 1 & 2 & 2 & 100 \\
$1-$ Global & Moderate & 1 & 5 & 3 & 2 & 1 & 1 & 1 & 70. \\
& Moderate Global & 1 & 1 & 1 & 7 & 4 & 1 & 4 & 20. \\
& Very Strong & 0 & 1 & 0 & 0 & 0 & 0 & 1 & 0.4 \\
& Very Strong Global & 0 & 0 & 0 & 0 & 0 & 0 & 0 & 0 \\
\hline & & 2 & 7 & 4 & 2 & 1 & 2 & 2 & 100 \\
\hline
\end{tabular}

Table 4 also indicates that for the learning styles dimensions which are dominated by balanced category, the very strong categories are minimal. For example, for sequential - global dimension in which the balanced category covers $70.67 \%$, the very strong category covers only $0.48 \%(0.48 \%$ for very strong sequential and $0 \%$ for very strong global). This also happens in active - reflective dimension, for which the very strong category covers only $3.85 \%$.

The next step is analyzing the relationship between the learning styles dimension of the students of EED UMK and their subject preference. This is done to investigate if there is a significant dependency relationship between subject preference and learning styles dimensions or to answer the question: "Is subject preference affected by learning styles dimensions of the students?" To calculate the value of $\chi^{2}$ (obtained) the degree of freedom $(d f)$ is $(6-1)(5-1)=20$ at $\alpha .05$. The result of the test is presented in Table 5 . 
Summary of the result of chi-square test of independence between subject preference and learning styles dimension at $X^{2}{ }_{.05} ; d f=20=$ 31.410

\begin{tabular}{|c|c|c|c|}
\hline $\begin{array}{l}\text { Independent } \\
\text { Variable }\end{array}$ & $\begin{array}{l}\text { Dependent } \\
\text { Variable }\end{array}$ & $\begin{array}{l}X^{2} \\
\text { (obtai } \\
\text { ned) }\end{array}$ & Conclusion \\
\hline $\begin{array}{l}\text { Active - Reflective } \\
\text { dimension }\end{array}$ & $\begin{array}{l}\text { Subject } \\
\text { preference }\end{array}$ & 22.62 & $\begin{array}{l}\text { not significant } \\
\text { at } \\
\alpha .05 ; d f=20\end{array}$ \\
\hline $\begin{array}{l}\text { Sensing - Intuitive } \\
\text { dimension }\end{array}$ & $\begin{array}{l}\text { Subject } \\
\text { preference }\end{array}$ & 32.081 & $\begin{array}{l}\text { significant at } \\
\alpha .05 ; d f=20\end{array}$ \\
\hline $\begin{array}{l}\text { Visual - Verbal } \\
\text { dimension }\end{array}$ & $\begin{array}{l}\text { Subject } \\
\text { preference }\end{array}$ & 59.905 & $\begin{array}{l}\text { significant at } \\
\alpha .05 ; d f=20\end{array}$ \\
\hline $\begin{array}{l}\text { Sequential - Global } \\
\text { dimension }\end{array}$ & $\begin{array}{l}\text { Subject } \\
\text { preference }\end{array}$ & 14.867 & $\begin{array}{l}\text { not significant } \\
\text { at } \\
\alpha .05 ; d f=20\end{array}$ \\
\hline
\end{tabular}

From Table 5 we can see that at $\alpha .05 ; d f=20$, only 2 learning styles dimensions which have significant dependency relationship with subject preference, i.e. Sensing - Intuitive and Visual - Verbal, while the other two, Active - Reflective and Sequential - Global, do not. In other words, based on these sample data, the probability of the students of having certain subject preference is not wholly dependent on Felder and Silverman's learning styles dimensions; only for Sensing - Intuitive and Visual - Verbal dimensions subject preference depends on. For these 2 learning style dimensions we can say that the students' subject preference depends on their learning styles dimensions.

Chi Square test cannot tell us whether the students whose subject preference is listening, for example, are more likely to be balanced, visual, or verbal. To figure out how subject preference is affecting learning styles preference, we can calculate the percentages within each column. From Table 4 we can see that the frequency for balanced category is 10 or 
$38.46 \%$, visual is 9 or $34.61 \%$, and verbal is 0 or $0 \%$. Comparing between visual and verbal dimensions, we can see that: 1) students whose subject preference is listening are more likely to be visual learners; and 2) the number of the students who are visual is greater than that of verbal in all subject preference.

Now that not all learning style dimensions have significant relationship with subject preference, both students and lecturers should pay attention to this phenomenon. This is because all students must take all of the subjects that have been included in the curriculum. Thus, students experience the learning styles of Sensing - Intuitive and Visual where Verbal have less freedom than those whose learning styles are Active - Reflective and Sequential - and Global, because Active Reflective and Sequential,as well as Global dimensions have no significant relationship with subject preference, while Sensing - Intuitive and Visual - Verbal do.

\section{CONCLUSIONS}

The conclusions which we can draw from the result of the analysis are that the general learning style profile of the students of EED MKU is balanced. In the level of significance $(\alpha) .05$ and degree of freedom $(d f) 4$, there is no significant relationship between gender and learning styles dimensions: the probability of the students of having certain learning styles dimension is independent on the gender of the students. In the level of significance $(\alpha) .05$ and degree of freedom 20, the probability of the students of EED MKU of having certain subject preference is not wholly dependent on their learning style dimensions: meanwhile, the subject preference of the students of EED MKU who are Sensing - Intuitive and Visual - Verbal depend on their learning styles dimensions, while that of those who are Active - Reflective and Sequential - Global do not.

Although the general profile of the learning styles category is balanced, it is suggested that each student understands his/her learning styles to know if he/she has an extreme learning style, i.e. very strong in certain dimension. By understanding his/her own learning styles he/she has reached one point of self-understanding, which is very important in SCL. This can be done quite easily by accessing sources which provide learning styles inventory, such as one which is used in this research, i.e. 
Index of Learning Styles Questionnaire from http://www.engr.ncsu.edu/ learning styles/ilsweb. html.

Because the general profile of the learning styles of the students of EED UMK is balanced $(60.10 \%)$ and there is no significant relationship between gender variable and learning styles variable, lecturers may choose various learning strategies. This prefered category of learning styles coresponds with various teaching styles.

It is also suggested to the lecturers to ask the students to inform their learning styles at the beginning of a course. Thus, it is recommended that further researchers use larger and more equal number of samples between males and females as in this research, where the number of female samples is greater than that of males.

The fact that only 2 dimensions of learning styles (Sensing Intuitive and Visual - Verbal) which have a significant relationship with subject preference leads us to suggest that the next researchers investigate those who have extreme dimensions of learning styles, i.e. those whose learning styles category is very strong in one dimension, in relation with their subject preference.

\section{REFERENCES}

Abidin, Mohamad Jafre Zainol, Rezaee, Abas Ali, Abdullah, Helan Nor, and Singh, Kiranjit Kaur Balbir. (2011). Learning Styles and Overall Academic Achievement in a Specific Educational System. International Journal of Humanities and Social Science, 1 (10), 143 - 152.

Benson, Phil. (2001). Teaching and Researching Autonomy in Language Learning. England: Pearson Education Limited.

Cohen, Andrew D. (1998). Strategies in Learning and Using a Second Language. London and New York: Longman. 
Departemen Pendidikan Nasional. (2005). Buku Tanya Jawab Kurikulum Berbasis Kompetensi.

Direktorat Jendral Pendidikan Tinggi. 2008. Buku Panduan Pengembangan Kurikulum Berbasis Kompetensi Perguruan Tinggi: sebuah alternatif penyusunan kurikulum.

Drysdale, Maureen T. B., Ross, Jonathan L., \& Schulz, Robert A. (2001). Cognitive Learning Styles and Academic Performance in 19 FirstYear University Courses: Successful Students Versus Students at Risk. Journal of Education for Students Placed at Risk (JESPAR), 6(3), abstract. Retrieved January 24, 2013 from http:// www.tandfonline.com/oi/df/10.1207/S15327671ESPR0603_7

Felder, Richard M and Silverman, Linda K. (1988). Learning and Teaching Styles in Engineering Education. Journal of Engineering Education, 78(7), 674-681.

Felder, Richard M and Henriques, Eunice R. (1995). Learning and Teaching Styles in Foreign and Second Language Education. Foreign Language Annals,.28 (1), 21 - 31.

Felder, R.M. (2002). Author's preface to Learning and Teaching Styles in Engineering Education. Journal of Engineering Education, 78(7), 674 681. Retrieved December 26, 2012 from: http://www4.ncsu.edu./unity/ lockers/users/f/felder/ public/Papers/LS- 1988.pdf.

Felder, R.M. (2013). (mfelder@mindspring.com). March 23, 2013. Re: Learning Styles Questionnaire. E-mail to Suprihadi (pakpriumk@gmail.com).

Felder, Richard M and Spurlin, Joni. (2005). Applications, Reliability and Validity of the Index of Learning Styles. Int. J. Engn,21 (1), 103-113.

Felder, Richard M and Soloman, Barbara A. (2012). Learning Styles and Strategies. Retrieved December 26, 2012 from http://www4.ncsu.edu/unity/lockers/users/f/felder/public/ILSdir/ styles. htm 
Johnson, R.B. EG Onwuegbuzie, N.J. (2004). Mixed Method Research: A Research Paradigm Whose Time Has Come. Educational Researcher, 33(7), 14. 26.

Liu, Min and Reed, W. Michael. (1994). The relationship between the Learning Strategies and Learning Styles in a Hypermedia Environment. Computers in Human Behavior, 10(4), abstract. Retrieved January 24, 2013 from http://www.sciencedirect. com/science/article/pii/ 0747563294900388

Macaro, Ernesto, Graham, Suzanne and Vanderplank, Robert. (2007). A review of listening strategies: focus on souces of knowledge and on success. In Andrew D Cohen, and Ernesto Macaro (Eds), Language Learner Strategies (pp. 165 - 185). Oxford: Oxford University Press.

Montemayor, Elizabeth, Apiaten, Maria C, Mendoza, Glen C, and Perey, Gemma M. (2009). Learning Styles of High and Low Academic Achieving Freshman Teacher Education Students: an Application of the Dunn and Dunn's Learning Style Model. University of the Cordilleras, Baguio City, Philippines, 01(4), 58 - 71.

Nelson, B., Dunn, R., Griggs., Primavera, L., Fitzpatrick, M., Bacilious, Z., and Miller, R. (1993). Effects of Learning Styles Intervention in College Students' Retention and Achievement. Journal of College Student Development. 34, 364-369.

O'Brien, Terrance P. (1991). Relationships among Selected Characteristics of College Students and Cognitive Style Preferences. College Student Journal, 25 (1), abstract. Retrieved January 25, 2013 from http://psycnet.apa. org/psycinfo/1991-22794-001.

Reid, Joy M. (1987). The Learning Styles of ESL Students. TESOL Quarterly, 21 (1), 87 - 111.

Solomon, Barbara. A and Felder, Richard M. Index of Learning Styles Questionnaire. Retrieved December 21, 2012 from: http://www.engr.ncsu.edu/ learningstyles/ilsweb.html. 
Sriachanyachon, Napaporn. (2012). The Relationship of Learning Styles, Learning Motivation and Academic Success in EFL Learning Context. Mediterranean Journal of Social Sciences, 3 (3), 211-216.

Summer Institute of Linguistics (SIL) International. (1999). What is a learning style? Retrieved December 21, 2012 from: http://www.sil.org/sil.

Trudgill, Peter. (1985). Sociolinguistics: An Introduction to Language and Society. London: Edward Arnold.

Vasyura, Svetlana A. (2008). Psychology of Male and Female Communicative Activity. Russia: Udmurt State University.

Wardhaugh, Ronald. (1992). An introduction to Sociolinguistics. New York: Blackwell.

\title{
APPENDIX 1:
}

Indonesian Version of Solomon-Felder Index of Learning Styles Questionnaire

(Translated into Indonesia under the permission of Richard M. Felder) and an example of an answer sheet

\section{Index of Learning Styles \\ Questionnaire}

\author{
Barbara A. Soloman \\ First-Year College \\ North Carolina State University \\ Raleigh, North Carolina 27695 \\ Richard M. Felder \\ Department of Chemical Engineering \\ North Carolina State University \\ Raleigh, NC 27695-7905
}

Kerjakan di lembar jawab yang disediakan dengan menyilang pilihan anda. 
Untuk masing-masing dari 44 pertanyaan berikut, pilih "a" atau "b" untuk menunjukkan jawaban anda. Pilih hanya satu jawaban untuk setiap pertanyaan. Bila pilihan "a" dan "b" anda anggap sesuai dengan kondisi anda, pilihlah yang paling sering terjadi/sesuai dengan diri anda.

1. Saya memahami sesuatu dengan lebih baik setelah saya ...

(a) mencobanya.

(b) memikirkannya secara mendalam.

2. Saya akan lebih suka dianggap sebagai orang yang ...

(a) realistis.

(b) inovatif.

3. Ketika saya memikirkan apa yang saya lakukan kemarin, yang muncul dalam benak saya cenderung berupa ...

(a) gambar/gambaran.

(b) kata-kata.

4. Dalam memahami sesuatu, saya cenderung ...

(a) mengerti detailnya tetapi mungkin bingung dengan bentuknya secara keseluruhan.

(b) mengerti bentuknya secara keseluruhan tetapi bingung dengan detailnya.

5. Sedang mempelajari sesuatu yang baru membantu saya untuk ...
(a) membicarakannya.
(b) memikikirkannya.

6. Bila saya menjadi guru, saya akan lebih suka mengajar mata pelajaran yang ...

(a) berkaitan dengan fakta-fakta dan situasi kehidupan nyata.

(b) berkaitan dengan ide-ide dan teori.

7. Saya lebih suka mendapatkan informasi baru dalam bentuk ...

(a) gambar, diagram, grafik, atau peta.

(b) tertulis atau informasi verbal.

8. Dalam memahami sesuatu, sekali saya memahami ...

(a) seluruh bagian-bagiannya, saya akan memahami bentuk utuhnya.

(b) bentuk utuhnya, saya tahu bagaimana bagian-bagiannya disatukan.

9. Dalam belajar kelompok mengerjakan materi yang sulit, saya lebih suka ... 
(a) langsung terlibat dan menyumbangkan ide.

(b) duduk di belakang dan mendengarkan dahulu.

10.Saya lebih mudah mempelajari...

(a) hal-hal yang nyata/fakta-fakta.

(b) konsep-konsep/teori.

11.Dalam buku yang berisi banyak gambar dan diagram, saya cenderung ...

(a) melihat gambar dan diagramnya dengan teliti.

(b) fokus pada teks tertulisnya.

12.Ketika menyelesaikan soal-soal matematika, ...

(a) saya biasanya mengerjakannya langkah demi langkah untuk mendapatkan hasilnya.

(b) saya sering melihat hasilnya dulu, tapi kemudian berusaha keras mengetahui langkah-lankahnya.

13. Dalam klas yang saya ikuti, ...

(a) saya biasanya kenal dengan kebanyakan mahasiswa.

(b) saya jarang kenal dengan kebanyakan mahasiswa.

14. Dalam mebaca bacaan non-fiksi, saya menyukai sesuatu yang ...

(a) mengajarkan fakta baru atau menunjukkan cara mengerjakan sesuatu.

(b) memberi ide baru untuk dipikirkan

15. Saya menyukai guru yang ...

(a) menggunakan banyak diagram di papan tulis.

(b) banyak menerangkan dengan kata-kata.

16. Ketika menganalisis sebuah cerita atau novel, ...

(a) saya memikirkan kejadian-kjadiannya dan mencoba merangkainya untuk mengetahui temanya.

(b) saya hanya tahu temanya ketika selesai membaca dan kemudian harus kembali membacanya untuk menemukan kejadian-kejadian yang membangun tema tersebut.

17. Ketika mulai mengerjakan PR, saya lebih suka ...

(a) langsung/segera mengerjakannya.

(b) berupaya memahami sungguh-sungguh permasalahannya lebih dahulu.

18.Saya lebih menyukai ...

(a) kepastian.

(b) teori. 
19.Saya paling mudah mengingat sesuatu yang ...

(a) saya lihat.

(b) saya dengar.

20.Menurut saya, penting bagi seorang instruktur untuk ...

(a) merancang materi dalam langkah-langkah yang jelas, tahap demi tahap.

(b) memberi saya gambaran utuhnya dan mengaitkan materi tersebut dengan mata pelajaran/kuliah lain.

21. Saya lebih menyukai belajar ...

(a) dalam kelompok belajar.

(b) sendiri.

22. Saya lebih suka dianggap ...

(a) teliti dengan detail-detail pekerjaan saya.

(b) kreatif dalam mengerjakan pekerjaan saya.

23.Ketika mendapat petunjuk menuju suatu tempat yang baru, saya lebih suka ...

(a) peta.

(b) petujuk tertulis.

24.Dalam mempelajari sesuatu, saya ...

(a) belajar dengan kecepatan biasa saja. Bila saya bekerja keras, saya akan "gets it."

(b) mempelajarinya langsung dengan cepat, kemudian akan mengalami kebingungan terlebih dahulu dan tiba-tiba segala sesuatunya "clicks" (beres).

25.Bila menghadapi pekerjaan, saya lebih suka terlebih dahulu...

(a) mencoba mengerjakan.

(b) memikirkan bagaimana cara mengerjakannya.

26. Ketia membaca untuk kesenangan (reading for enjoyment), saya menyukai penulis yang ...

(a) mengatakan dengan lugas dan jelas apa maksud mereka.

(b) mengatakan segala sesuatunya dengan cara yang kreatif dan menarik.

27. Ketika melihat diagram atau sketsa di kelas, yang paling saya ingat adalah
(a) gambarnya.
(b) apa yang dikatakan guru tentang gambar itu. 
28.Dalam memahami suatu informasi, saya cenderung ...

(a) fokus pada detailnya dan tidak mendapatkan gambaran umumnya.

(b) mencoba memahami gambaran umumnya sebelum memahami detailnya.

29. Saya lebih mudah mengingat ...

(a) sesuatu yang telah saya kerjakan.

(b) sesuatu yang telah banyak/lama saya pikirkan.

30. Ketika harus melaksanakan tugas, saya lebih suka ...

(a) menggunakan satu cara yang sudah ada.

(b) mencari cara-cara baru.

31. Bila seseorang menunjukkan data kepada saya, saya lebih menyukainya dalam bentuk ...
(a) diagram atau grafik.
(b) teks tentang ringkasan hasilnya.

32. Dalam menyusun makalah, saya lebih senang...
(a) mengerjakan (di pikiran atau ditulis) bagian awalnya kemudian bagian-bagian selanjutnya secara runtut.
(b) mengerjakan (di pikiran atau ditulis) bagian yang berbeda-beda dan kemudian mengurutkannya.

33. Bila harus mengerjakan tugas kelompok, saya ingin terlebih dahulu ...
(a) mengadakan "group brainstorming" dimana setiap anggota menyumbangkan ide masing-masing.
(b) melakukan "brainstorming" secara individu kemudian berkumpul untuk membandingkan/membahas ide yang muncul.

34. Menurut saya, adalah sebuah penghormatan baginya bila saya menyebut dia sebagai orang yang ...
(a) penuh perasaan (sensible).
(b) penuh imaginasi (imaginative).

35. Bila bertemu orang di sebuah pesta, yang lebih saya ingat adalah ...
(a) penampilan mereka/ seperti apa mereka.
(b) apa yang mereka katakan tentang diri mereka sendiri.

36. Bila mempelajari sesuatu yang baru, saya lebih suka ...
(a) tetap fokus pada hal tersebut, belajar sebanyak mungkin tentang hal tersebut.
(b) berupaya menghubungkan hal tersebut dengan hal-hal yang terkait. 
37. Saya lebih suka dianggap sebagai orang yang...
(a) mudah bergaul (outgoing).
(b) pendiam/tidak banyak bicara (reserved).

38. Saya lebih menyukai mata pelajaran/kuliah yang menekankan pada ...
(a) materi yang kongkret (fakta, data).
(b) materi yang abstrak (konsep, teori).

39. Untuk hiburan, saya lebih memilih ...
(a) nonton acara televisi.
(b) membaca buku.

40. Beberapa dosen memulai perkuliahan dengan menunjukkan garis besar (outline) materi yang akan disajikan. Outline seperti itu ...
(a) sedikit membantu saya.
(b) sangat membantu saya.

41. Mengerjakan PR secara kelompok dimana nilainya sama untuk anggota adalah ...
(a) menarik untuk saya.
(b) tidak menarik untuk saya.

42. Bila melakukan hitung-hitungan yang panjang, saya ...
(a) cenderung mengulang semua langkah dan mengecek kembali pekerjaan saya dengan teiliti.
(b) mengecek kembali pekerjaan saya adalah sesuatu yang melelahkan dan saya harus memaksa diri saya untuk melakukannya.

43. Saya cenderung dapat membayangkan tempat yang pernah saya kunjungi dengan ...
(a) mudah dan dengan cukup akurat.
(b) susah payah dan tanpa banyak detail.

44. Dalam menyelesaikan permasalahan dalam kelompok, saya cenderung ...
(a) memikirkan langkah-langkahnya selama dalam proses penyelesaian masalah tersebut (sambil jalan).
(b) memikirkan berbagai kemungkinan penyelesaian masalah tersebut secara luas.

This is the end of the questionnaire.

Thank you very much. 


\section{ANSWER SHEET}

\section{Respondent Identity}

1. Full name

2. Student Number

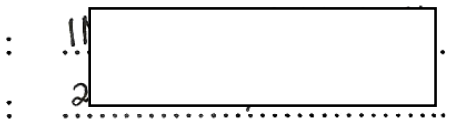

3. Group

4. Sex

a. Male

(b) Female*)

5. Subject Preference
a. Listening
b. Speaking
c. Reading
d. Writing*

e. Another

6. Cumulative Grade Point Average (IPK) $=3,4$

*) Circle your choice.

${ }^{* *}$ ) Mention if you have another subject preference.

\begin{tabular}{|c|c|c|}
\hline 1. & $\mathrm{a}$ & 奴 \\
\hline 2. & 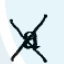 & b \\
\hline 3. & $X$ & $b$ \\
\hline 4. & $\mathrm{a}$ & $\not \alpha$ \\
\hline 5. & $\mathbf{a}$ & $x$ \\
\hline 6. & $x$ & $\mathrm{~b}$ \\
\hline 7. & $\mathrm{a}$ & 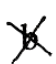 \\
\hline 8. & $x$ & $\mathrm{~b}$ \\
\hline 9. & $x$ & $\mathrm{~b}$ \\
\hline 10. & $x$ & $\mathrm{~b}$ \\
\hline 11. & $\alpha$ & $\mathrm{b}$ \\
\hline
\end{tabular}

\begin{tabular}{|c|c|c|c|c|c|}
\hline 12. & $x$ & $\mathrm{~b}$ & 23. & $\mathrm{a}$ & $\not x$ \\
\hline 13. & $\alpha$ & $b$ & 24. & $\not$ & $\mathrm{b}$ \\
\hline 14. & $x$ & b & 25. & $x$ & b \\
\hline 15. & $x$ & $\mathrm{~b}$ & 26. & $x$ & $\mathrm{~b}$ \\
\hline 16. & $x$ & b & 27. & 2 & $\mathrm{~b}$ \\
\hline 17. & 2 & b & 28. & $\mathrm{a}$ & 为 \\
\hline 18. & $x$ & b & 29. & X & $\mathrm{b}$ \\
\hline 19. & $\mathrm{a}$ & $\not \alpha$ & 30. & $\not x$ & $\mathrm{~b}$ \\
\hline 20. & $\mathrm{a}$ & $\not x$ & 31. & $\mathrm{a}$ & $\not \alpha$ \\
\hline 2.1 & $x$ & b & 32. & $x$ & b \\
\hline 22 & $\mathrm{a}$ & 双 & 33. & $x$ & b \\
\hline
\end{tabular}

\begin{tabular}{|c|c|c|}
\hline 34. & $\mathrm{a}$ & 1 \\
\hline 35. & $x$ & $\mathrm{~b}$ \\
\hline 36. & $\mathrm{a}$ & 16 \\
\hline 37. & $\alpha$ & $b$ \\
\hline 38. & $x$ & $\mathrm{~b}$ \\
\hline 39. & $x$ & $b$ \\
\hline 40 & $x$ & $\mathrm{~b}$ \\
\hline 41. & $\not x$ & b \\
\hline 42. & $x$ & b \\
\hline 43. & $x$ & b \\
\hline 44. & & b \\
\hline
\end{tabular}




\section{APPENDIX 2:}

the result of analysis by the system

NO STATE UNIVERSITY

\section{Learning Styles Results}

Results for:

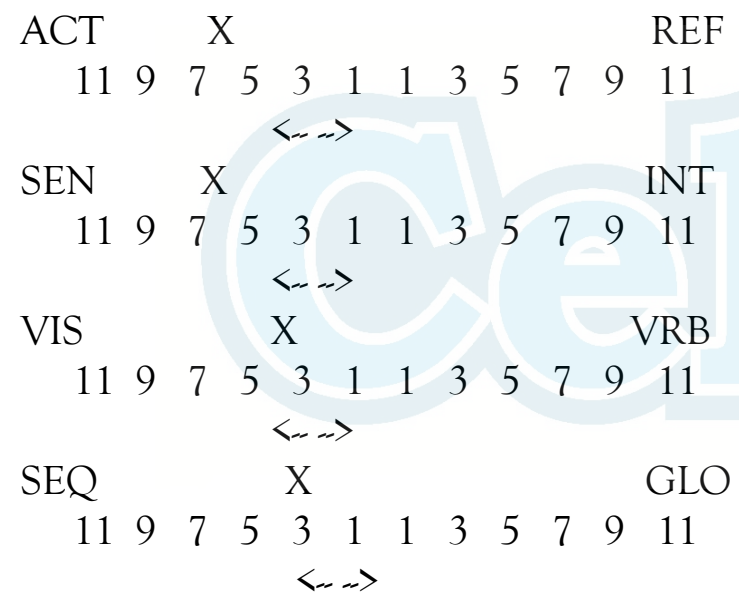

- If your score on a scale is 1-3, you are fairly well balanced on the two dimensions of that scale.

- If your score on a scale is 5-7, you have a moderate preference for one dimension of the scale and will learn more easily in a teaching environment which favors that dimension.

- If your score on a scale is 9-11, you have a very strong preference for one dimension of the scale. You may have real difficulty learning in an environment which does not support that preference. 
270 Celt, Volume 16, Number 2, December 2016, pp. 242-270

We suggest you print this page, so that when you look at the explanations of the different scales you will have a record of your individual preferences.

For explanations of the scales and the implications of your preferences, click on Learning Style Descriptions.

For more information about learning styles or to take the test again, click on Learning Style Page. 